\title{
Berberis libanotica extract targets NF-кB/COX-2, PI3K/Akt and mitochondrial/caspase signalling to induce human erythroleukemia cell apoptosis
}

\author{
SAADA DIAB ${ }^{1}$, CHLOE FIDANZI $^{1}$, DAVID Y. LÉGER ${ }^{1}$, LAMIA GHEZALI $^{1}$, MARION MILLOT $^{1}$, \\ FRÉDÉRIQUE MARTIN ${ }^{1}$, RANIA AZAR ${ }^{2}$, FADI ESSEILY ${ }^{3}$, ANTOINE SAAB ${ }^{4}$, \\ VINCENT SOL $^{1}$, MONA DIAB-ASSAF ${ }^{2}$ and BERTRAND LIAGRE ${ }^{1}$
}

\footnotetext{
${ }^{1}$ Laboratory of Chemistry of Natural Substances, Faculty of Pharmacy, University of Limoges, FR 3503 GEIST, EA1069, Limoges, France; ${ }^{2}$ Molecular Tumorigenesis and Anticancer Pharmacology, EDST, Lebanese University, Hadath;

${ }^{3}$ Laboratory Science Department, Faculty of Public Health, Lebanese University, Jdeidet El Metn;

${ }^{4}$ Faculty of Sciences II, Chemistry Department, Lebanese University, Beirut, Lebanon
}

Received March 10, 2015; Accepted April 7, 2015

DOI: $10.3892 /$ ijo.2015.3012

\begin{abstract}
The aim of this study was to describe and understand the relationship between cyclooxygenase-2 (COX-2) expression and apoptosis rate in erythroleukemia cells after apoptosis induction by Berberis libanotica (Bl) extract. To achieve this goal we used erythroleukemia cell lines expressing COX-2 (HEL cell line) or not (K562 cell line). Moreover, we made use of COX-2 cDNA to overexpress COX-2 in K562 cells. In light of the reported chemopreventive and chemosensitive effects of natural products on various tumor cells and animal models, we postulated that our $B l$ extract may mediate their effects through apoptosis induction with suppression of cell survival pathways. Our study is the first report on the specific examination of intrinsic apoptosis and $\mathrm{Akt} / \mathrm{NF}-\mathrm{\kappa B} / \mathrm{COX}-2$ pathways in human erythroleukemia cells upon $B l$ extract exposure. Even if $B l$ extract induced apoptosis of three human erythroleukemia cell lines, a dominant effect of $\mathrm{Bl}$ extract treatment on K562 cells was observed resulting in activation of the late markers of apoptosis with caspase-3 activation, PARP cleavage and DNA fragmentation. Whereas, we showed that $B l$ extract reduced significantly expression of COX-2 by a dose-dependent manner in HEL and K562 $\left(\mathrm{COX}-2^{+}\right)$cells. Furthermore, in regard to our results, it is clear that the simultaneous inhibition of Akt and NF- $\mathrm{KB}$ signalling can significantly contribute to the anticancer effects of $B l$ extract in human erythroleukemia cells. We observed that
\end{abstract}

Correspondence to: Professor Bertrand Liagre, Laboratory of Chemistry of Natural Substances, Faculty of Pharmacy, University of Limoges, FR 3503 GEIST, EA1069, Limoges, France

E-mail: bertrand.liagre@unilim.fr

Key words: Berberis libanotica, COX-2, NF-кB, PI3K/Akt, apoptosis, erythroleukemia cells the $B l$ extract is clearly more active than the berberine alone on the induction of DNA fragmentation in human erythroleukemia cells.

\section{Introduction}

Cyclooxygenases (COX) are inflammatory regulators that mediate the production of prostaglandins from arachidonic acid. Two COX isoforms have been identified (1). COX-1 is constitutively expressed and maintains homeostatic level of prostaglandins, whereas COX-2 is induced by growth factors, tumor promoters, and cytokines (2). To date, COX-2 has been found to be highly expressed in many types of solid cancers including breast, prostate, colon and lung $(3,4)$ and to contribute to tumorigenesis via the inhibition of apoptosis, increased angiogenesis and invasiveness (4). Moreover, in many of these cancer types, an elevated COX-2 expression was correlated with a poor response to therapy and decreased survival (5).

Concerning hematological malignancies, Bernard et al (6) highlighted the recent interest in studying and modulating COX-2 expression in cells of hematopoietic origin. They described the different studies that were conducted on the impact of COX-2 expression in hematological diseases and showed that chronic lymphocytic leukemia, chronic myeloid leukemia, Hodgkin's lymphoma, non-Hodgkin's lymphoma and multiple myeloma all highly express COX-2 and that elevated COX-2 expression is often correlated with decreased survival of patients with hematological malignancies (6). As for acute myeloid leukemia, COX-2 has been shown to be expressed in various cell lines and functional genetic variations of COX-2 have been recently correlated to susceptibility to acute myeloid leukemia $(7,8)$. However, there are scarce data focused on the effect of COX-2 expression in erythroleukemia cells, a subtype of acute myeloid leukemia with a very poor response and survival to current available therapeutic agents (9).

The interest on COX-2 activity in hematological malignancies has also been reinforced by the use of NSAIDs and COX-2 
selective inhibitors in vitro, to induce proliferation arrest and apoptosis in leukemia cells $(6,10,11)$. Furthermore, it was also shown that targeting COX-2 reduced toxicity toward low-dose chemotherapy with vinblastine and extended survival in an erythroleukemia model of juvenile mice with Friend disease (12).

Despite this evident interest of COX-2 modulation in leukemia cells, literature lacks detailed data on the role of COX-2 in myeloid leukemia onset and management and particularly in cases of erythroleukemia.

Berberis libanotica $(\mathrm{Bl})$, specifically the roots, has been used in traditional herbal Lebanese remedies for rheumatic and neuralgic diseases $(13,14)$. B. vulgaris and B. stata are the two most studied species of Berberis (15-18). Alkaloids constitute the major class of compounds reported to exist in Berberis species and represent a very wide range of secondary metabolites with important biological activities $(19,20)$. Various herbal alkaloids exhibit in vitro and in vivo anti-proliferative and anti-metastatic effects on various types of cancers. Alkaloids, such as camptothecin (21) and vinblastine (22), have already been successfully developed into anticancer drugs. Berberine, a major alkaloid characterizing Berberis species, has been intensively investigated for its pharmacological properties. It was shown to inhibit the migration of melanoma cancer cells (23), and the growth of human tongue squamous carcinoma tumors in a murine xenograft model (24), enhance tumor necrosis factor-related apoptosis-inducing ligand in breast cancer (25), and exert a cytotoxic effect against many cell lines $(23,26,27)$. To date, the biological and phytochemical properties of $B l$ extracts have only been investigated in three studies reporting the inhibition of adult T-cell leukaemia viability via ethanol fraction (28), the inhibition of key enzymes linked to Alzheimer's disease (13), and the anti-neoplastic effects on prostate cancer stem/progenitor cells (29).

In this overall context, the aim of this study was to describe and understand the relationship between COX-2 expression and apoptosis rate in erythroleukemia cells after apoptosis induction by $B l$ extract. To achieve this goal we used erythroleukemia cells lines expressing COX-2 (HEL cell line) or not (K562 cell line). Moreover, we made use of COX-2 cDNA to overexpress COX-2 in K562 cells. Then, to understand the mechanisms implicated in the effect of $B l$ extract, we studied intracellular signalling pathways.

\section{Materials and methods}

Materials. RPMI-1640, fetal calf serum (FCS) and penicillin streptomycin were supplied by Gibco BRL (Cergy Pontoise, France). Human antibody against caspase-9 was purchased from Cell Signaling Technology (Ozyme, France), poly-ADPribose polymerase (PARP), p-Akt antibodies were purchased from Santa Cruz Biotechnology (Tebu-Bio, Le Perray en Yvelines, France), cyclooxygenase-2 (COX-2) and $\beta$-actin were respectively purchased from Cayman Chemical (Bertin Pharma, Montigny le Bretonneux, France) and Sigma-Aldrich (Saint Quentin Fallavier, France).

Berberis libanotica extraction and HPLC. Berberis libanotica was collected from Ehden, North of Lebanon, in November 2012 at an altitude up to $1521 \mathrm{~m}$. Botanical identity was authen- ticated by Professor S. Safi, Biology Department, Faculty of Science II, Lebanese University, Fanar, Lebanon. Powdered root material $(10 \mathrm{~g})$ was extracted with ethanol $(100 \mathrm{ml})$ for $48 \mathrm{~h}$ under magnetic stirring at room temperature, then it was filtered using Whatman paper number 1 , and concentrated using a rotator evaporator. The extraction method used has been reported (30). The filtred extract was dried with liquid nitrogen and stored at $4^{\circ} \mathrm{C}$.

HPLC was done on a Waters Alliance 2690 using a reversed-phase $\mathrm{C} 18 \mathrm{X}$-Terra ${ }^{\circledR} 5 \mu \mathrm{m}(150 \times 4.6 \mathrm{~mm})$ and using a photodiode-array detector (Waters 996). TLC was performed on pre-coated silica gel aluminium sheets (kieselgel 60 F254, $0.20 \mathrm{~mm}$, Merck). Visualisation of plates was carried out under UV light (254 and $365 \mathrm{~nm}$ ) and using Draggendorf reagent. Compounds were identified by HPLC (RP-18 column, $\mathrm{ACN}-\mathrm{H}_{2} \mathrm{O}-\mathrm{H}_{3} \mathrm{PO}_{4}$, flow rate, $1 \mathrm{ml} / \mathrm{min}$ ) with $\mathrm{CHCL}_{3} / \mathrm{MeOH} /$ $\mathrm{NH}_{4} \mathrm{OH}(80 / 20 / 0.5)$.

Cells lines and cell culture. The HEL and K562 human erythroleukemia cell lines were kindly provided, respectively, by Professor J.P. Cartron (INSERM U76, Paris, France) and Dr I. Dusanter-Fourt (INSERM U567, CNRS UMR 8104, Paris, France). Cells were seeded at $10^{5}$ cells $/ \mathrm{ml}$ in $75-\mathrm{cm}^{2}$ tissue culture flasks and grown in RPMI-1640 medium (Gibco BRL, Cergy-Pontoise, France) supplemented with $10 \%$ fetal calf serum (Gibco BRL), $1 \%$ sodium pyruvate, $1 \%$ HEPES (N-(2-hydroxyethyl)piperazine-N'-2-ethanesulfonic acid), $100 \mathrm{U} / \mathrm{ml}$ penicillin and $100 \mu \mathrm{g} / \mathrm{ml}$ streptomycin (Gibco BRL). Cultures were maintained in a humidified atmosphere with $5 \% \mathrm{CO}_{2}$ at $37^{\circ} \mathrm{C}$. Cells were allowed to grow for $24 \mathrm{~h}$ in culture medium prior to exposure or not to $40-300 \mu \mathrm{g} / \mathrm{ml} \mathrm{Bl}$ extract or 20 and $40 \mu \mathrm{M}$ berberine (Sigma-Aldrich) for 6-72 h.

COX-2 cDNA transfection. COX-2 transfection-ready cDNA was purchased from OriGene Technologies (Rockville, MD, USA) and was transfected to K562 cells by electroporation using the AMAXA Nucleofactor system (Lonza). Stable K562 cell line was obtained after transfection and selection with $0.5 \mathrm{mg} / \mathrm{ml}$ of neomycin (G418, Sigma-Aldrich). COX-2 expression was confirmed by western blotting.

Cell proliferation and lactate dehydrogenase (LDH) assays. Measurement of cell proliferation was determined using the 3-(4,5-dimethylthiazol-2-yl)-2,5-diphenyltetrazolium bromide (MTT) assay. HEL, K562 and K562 (COX-2 ${ }^{+}$) cells were cultured and plated, respectively, at $10^{5}$ cells $/ \mathrm{ml}$ in $10 \%$ FCS medium in 96-well culture plates and grown $24 \mathrm{~h}$ before treatment or not (time 0 ) with $50-300 \mu \mathrm{g} / \mathrm{ml} B l$ extract for 24-72 h. MTT tests were carried out daily as previously described (31) and experiments were performed in three independent assays.

The cytotoxicity of $B l$ extract on the three cell lines was determined by measuring the activity of LDH released from the cytosol of damaged cells using a Cytotoxicity Detection kit PLUS (LDH) (Roche Diagnostics GmbH). The assay was conducted following the manufacturer's instructions. Briefly, medium supernatants of control and treated cells were collected and equal volume of reaction mixture was added. The reaction mixtures were incubated for $20 \mathrm{~min}$ at room temperature in the dark. Following incubation, the absorbance 
was determined at $490 \mathrm{~nm}$ using an ELISA plate reader. The percentage of cytotoxicity was calculated according to the manufacturer's instructions.

Mitochondrial membrane potential $(\Delta \psi m) . \Delta \psi \mathrm{m}$ was estimated using 5,5',6,6'-tetrachloro-1,1',3,3'-tetraethylbenzimidazole carbocyanide iodide (JC-1, Molecular Probes). JC-1 is a fluorescent compound that exists as a monomer at low concentrations. At higher concentrations, it forms aggregates. Fluorescence of the JC-1 monomers is green, whereas that of aggregates is red. Mitochondria with intact membrane potential concentrate JC-1 into aggregates, which fluoresces red, whereas de-energized mitochondria cannot concentrate it and are stained green $(31,32)$.

HEL, K562 and K562 (COX-2 $2^{+}$cells were grown for $24 \mathrm{~h}$ before treatment with $50-300 \mu \mathrm{g} / \mathrm{ml} \mathrm{Bl}$ extract for 6 and $24 \mathrm{~h}$. Control cells were grown in medium containing the same amount of vehicle as treated cells. Then cells were incubated in $1 \mathrm{ml}$ of medium containing JC-1 $(1 \mu \mathrm{g} / \mathrm{ml})$ for $30 \mathrm{~min}$ at $37^{\circ} \mathrm{C}$ and images were taken with a confocal laser microscope (Zeiss LSM 510 Meta).

Protein expression. After treatment, HEL, K562 and K562 $\left(\mathrm{COX}-2^{+}\right)$cells were washed and lysed in RIPA lysis buffer (50 mM HEPES pH 7.5, $150 \mathrm{mM} \mathrm{NaCl,} \mathrm{1 \%} \mathrm{deoxycholate,}$ $1 \% \mathrm{NP}-40,0.1 \% \mathrm{SDS}, 20 \mu \mathrm{g} / \mathrm{ml}$ aprotinin) containing protease inhibitors (Complete ${ }^{\mathrm{TM}}$ Mini, Roche Diagnostics, Meylan, France). Briefly, as previously described (33), proteins $(10-100 \mu \mathrm{g})$ were separated by electrophoresis on SDS-polyacrylamide gels, transferred to PVDF membranes (Amersham Pharmacia Biotech, Saclay, France) and probed with respective human antibodies against caspase-9 (Cell Signaling Technology, Ozyme, France), poly-ADP-ribose polymerase (PARP), p-Akt (Santa Cruz Biotechnology) and COX-2 (Cayman Chemical, Bertin Pharma). After incubation with secondary antibodies (Dako France S.A.S., Trappes, France), blots were developed using the ECL Plus Western Blotting Detection system (Amersham Pharmacia Biotech) and G:BOX system (Syngene, Ozyme, Saint Quentin en Yvelines, France). Membranes were then reblotted with anti$\beta$-actin (Sigma-Aldrich) used as a loading control.

Caspase-3 activity. Caspase-3 activity was assayed using Quantikine ${ }^{\circledR}$ human active caspase-3 (R\&D Systems) as previously described (34). HEL, K562 and K562 (COX-2 $\left.{ }^{+}\right)$ cells were treated or not with $50-300 \mu \mathrm{g} / \mathrm{ml} B l$ extract for 24 and $48 \mathrm{~h}$, and then incubated with $10 \mu \mathrm{M}$ biotin-ZVKD-fmk inhibitor for $1 \mathrm{~h}$ at $37^{\circ} \mathrm{C}$. Caspase-3 activity was measured in accordance with the manufacturer's protocol (R\&D Systems). Briefly, cells were harvested, washed in PBS and resuspended in extraction buffer containing protease inhibitors. Standards and sample extracts containing covalently linked active caspase-3-ZVKD-biotin were added to a microplate precoated with monoclonal antibody specific for caspase- 3 . Then, streptavidin conjugated to horseradish peroxidase was added to the wells. The amount of active caspase- 3 was quantified by colorimetry at $450 \mathrm{~nm}$ after addition of HRP substrate.

Apoptosis quantification: DNA fragmentation. HEL, K562 and $\mathrm{K} 562\left(\mathrm{COX}-2^{+}\right)$cells were seeded at $10^{5}$ cells $/ \mathrm{ml}$ in $75-\mathrm{cm}^{2}$ tissue culture flasks and then treated or not with $50-300 \mu \mathrm{g} / \mathrm{ml}$ $B l$ extract for 24 and $48 \mathrm{~h}$, or with 20 and $40 \mu \mathrm{M}$ berberine for $48 \mathrm{~h}$. Apoptosis was quantified on pooled cells (floating and adherent) using 'cell death' enzyme-linked immunosorbent assay (ELISA) (Cell Death Detection ELISAPlus, Roche Diagnostics). Cytosol extracts were obtained according to the manufacturer's protocol and apoptosis was measured as previously described (35).

Subcellular protein fractionation. HEL and K562 (COX-2 $\left.{ }^{+}\right)$ cells were incubated alone or with $300 \mu \mathrm{g} / \mathrm{ml} \mathrm{Bl}$ extract for 12,24 and $48 \mathrm{~h}$, or with 20 and $40 \mu \mathrm{M}$ berberine for $48 \mathrm{~h}$. Cytosolic and nuclear fractions were obtained using the Subcellular Protein Fractionation kit according to the manufacturer's protocol (Thermo Fischer Scientific, Rockford, IL, USA) as previously described (31).

Electromobility shift assay (EMSA). EMSA experiments were performed using DIG Gel Shift kit (Roche Diagnostics) (36). Briefly, nuclear extracts were prepared from HEL and $\mathrm{K} 562\left(\mathrm{COX}-2^{+}\right)$cells treated or not with $300 \mu \mathrm{g} / \mathrm{ml} \mathrm{Bl}$ extract for 12,24 and $48 \mathrm{~h}$, or with 20 and $40 \mu \mathrm{M}$ berberine for $48 \mathrm{~h}$. NF- $\mathrm{KB}$ binding reactions were carried out with $10 \mu \mathrm{g}$ nuclear proteins incubated with digoxigenin (DIG) labeled $\mathrm{NF}-\kappa \mathrm{B}$ probe according to the manufacturer's protocol. The samples were loaded on a $5 \%$ native polyacrylamide gel in Tris-borate-EDTA buffer. After transfer to nylon membranes and incubation with anti-DIG antibody conjugated with alkaline phosphatase, gel mobility shift was visualized by incubation with $\mathrm{CSPD}^{\circledR}$ chemiluminescence reagent and G:BOX system (Syngene). Quantification of each band was performed by densitometry analysis software in respect of band intensity and band area. Results are expressed relative to controls in arbitrary units.

Statistical analysis. Data are expressed as the arithmetic means \pm standard deviation (SD) of separate experiments. The statistical significance of results obtained from in vitro studies was evaluated by the two tailed unpaired Student's t-test, with $\mathrm{p}<0.05$ being considered as statistically significant.

\section{Results and Discussion}

The HPLC chromatogram show three main peaks at $t_{R}=12.5$, 17.5 and $20.1 \mathrm{~min}$ (Fig. 1A). By comparing the control, we found that the peak with a $t_{R}=20$ min matches to berberine. The two other peaks matched with alkaloids derived from berberine regarding close similarities between their UV spectrum and the UV spectrum of the control (Fig. 1B).

In light of the reported chemopreventive and chemosensitive effects of natural products on various tumor cells and animal models, we postulated that our $B l$ extract may mediate its effects through apoptosis induction with suppression of cell survival pathways. Our study is the first report on the specific examination of intrinsic apoptosis and Akt/NF- $\mathrm{B} / \mathrm{COX}-2$ pathways in human erythroleukemia cells upon $B l$ extract exposure.

In this study, we aimed to establish cellular models of erythroleukemia cells in which we could study the effect of COX-2 expression. As COX-2 has been widely implicated in 


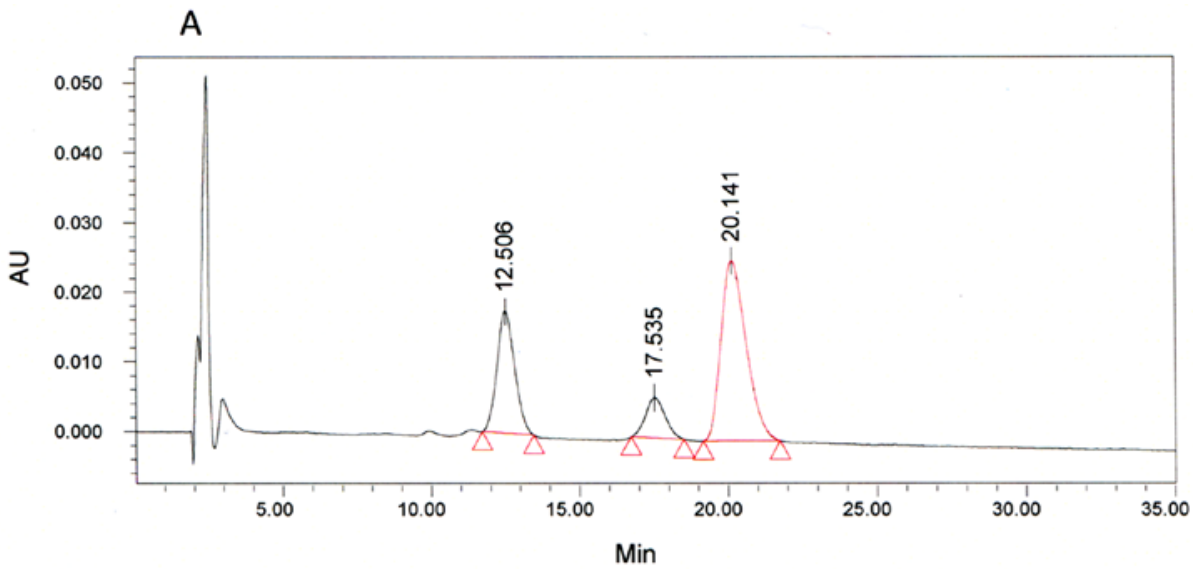

\section{B}
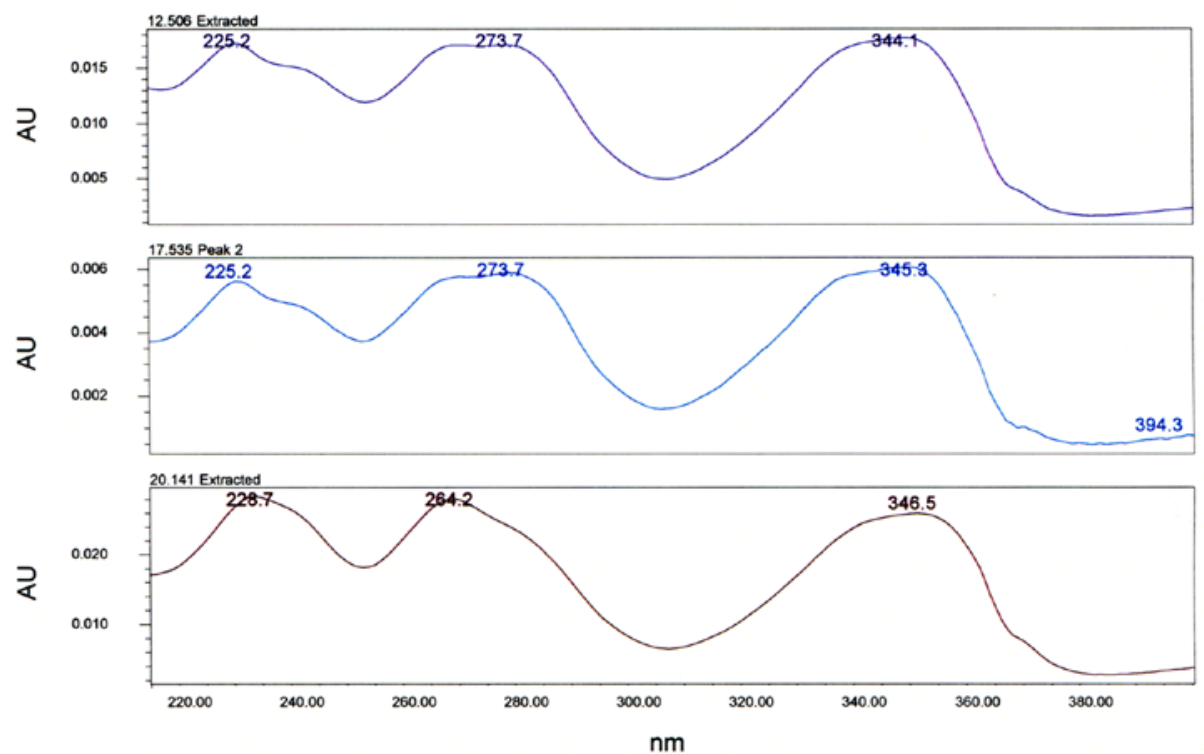

Figure 1. HPLC chromatogram (A) and UV spectra of the three main peaks of ethanolic extract of Berberis libanotica (B).

HEL

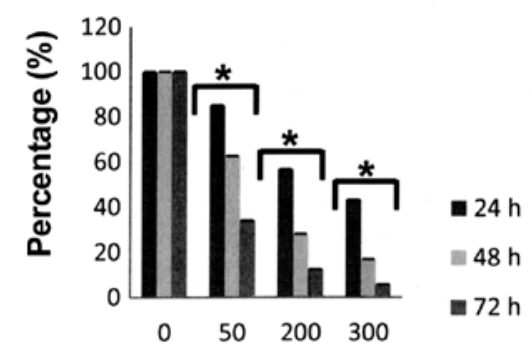

Concentration $(\mu \mathrm{g} / \mathrm{ml})$
K562

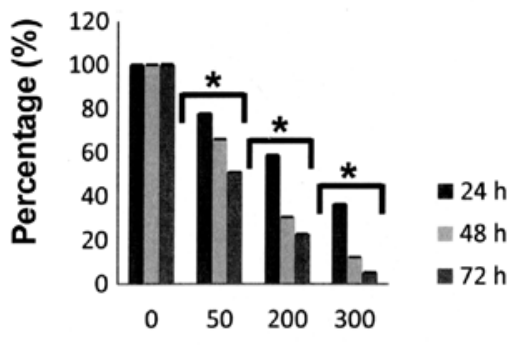

Concentration $(\mu \mathrm{g} / \mathrm{ml})$

\section{K562(COX-2+)}

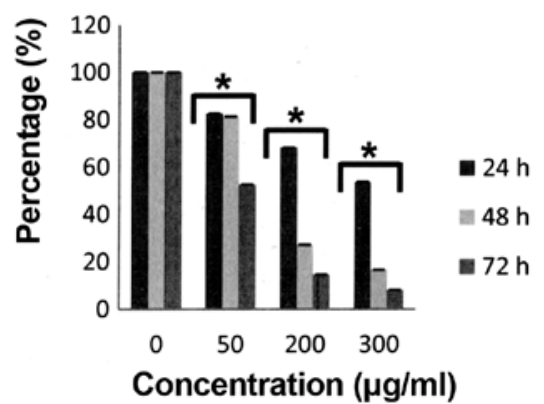

Figure 2. Effect of $\mathrm{Bl}$ extract on human erythroleukemia cell growth. Cells were cultured in $10 \%$ FCS medium during $24 \mathrm{~h}$ and treated or not with $50-300 \mu \mathrm{g} / \mathrm{ml} \mathrm{Bl}$ extract for 24-72 h. Cell proliferation was followed by MTT test. ${ }^{*}$ p $<0.05$ versus control. 
HEL

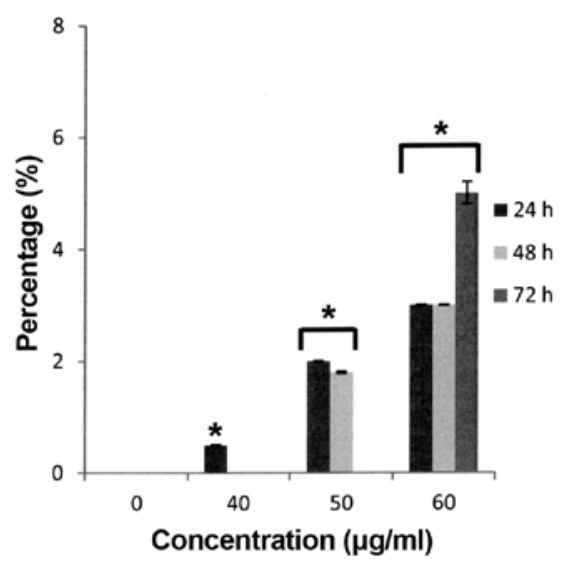

K562

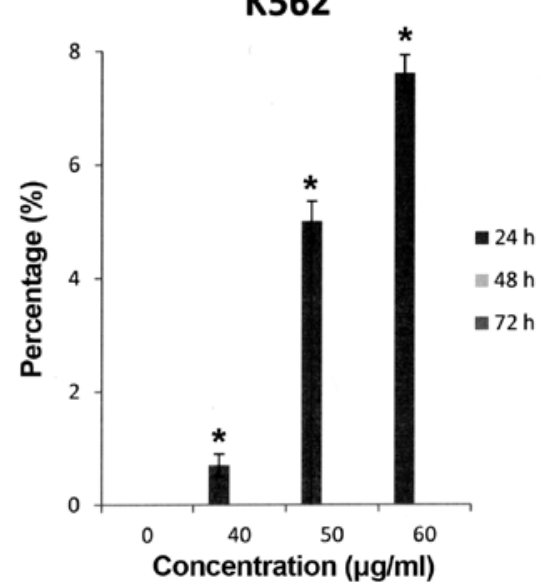

Figure 3. Effect of $B l$ extract on human erythroleukemia cell cytotoxicity. Cells were cultured in $10 \%$ FCS medium during $24 \mathrm{~h}$ and treated or not with $40-60 \mu \mathrm{g} / \mathrm{ml} \mathrm{Bl}$ extract for $24-72 \mathrm{~h}$. Cell cytotoxicity was followed by LDH test. " $\mathrm{p}<0.05$ versus control.

apoptosis resistance in various cancer cells (4,37-39) including leukemia cells $(6-8,40)$, we further checked for the first time whether COX-2 expression could modulate apoptosis induction by $B l$ extract in erythroleukemia cells.

We first demonstrated that, under our experimental conditions, a decrease in proliferation was observed as early as $24 \mathrm{~h}$ after $B l$ extract treatment in a dose- and time-dependent manner for the three cell lines (Fig. 2) without significative difference between K562 and K562 (COX-2 $2^{+}$cells. Furthermore, $B l$ extract engendered only a very low cytotoxicity on HEL cells $(5.2 \%$ at $60 \mu \mathrm{g} / \mathrm{ml}$ for $72 \mathrm{~h}$ versus control, $\mathrm{p}<0.05)$ and $\mathrm{K} 562$ cells $(7.8 \%$ at $60 \mu \mathrm{g} / \mathrm{ml}$ for $72 \mathrm{~h}$ versus control, $\mathrm{p}<0.05$ ) (Fig. 3).

Apoptosis is characterized by chromatin condensation and DNA fragmentation, and is mediated by caspases (41). Mitochondria are involved in a variety of key events, including release of caspase activators, changes in electron transport, loss of mitochondrial membrane potential $(\Delta \psi \mathrm{m})$, and participation of both pro- and anti-apoptotic Bcl-2 family proteins (42). Alterations in mitochondrial structure and function have been shown to play a crucial role in caspase-9-dependent apoptosis (43). Caspase-9 cleaves and activates caspase-3, the executioner caspase, which cleaves PARP and activates endonucleases leading to DNA fragmentation (43). Mitochondria have, apart from their function in respiration, an important role in the apoptotic-signalling pathway. It is well known that the modification of $\Delta \psi \mathrm{m}$ depends on the nature of the stimulus and the cell system and the collapse of $\Delta \psi \mathrm{m}$ is an early step in the apoptotic cascade (44). To determine potential mechanisms by which $B l$ extract inhibited the human erythroleukemia cell proliferation, we analyzed the effect of $B l$ extract on $\Delta \psi \mathrm{m} . \Delta \psi \mathrm{m}$ was analyzed after 6- and 24-h treatment with $B l$ extract using JC-1. We found that $B l$ extract decreased $\Delta \psi \mathrm{m}$ in a dose- and time-dependent manner for the three cell lines (Fig. 4), shown by the incorporation of JC-1 monomers into mitochondria (green fluorescence), compared with cytosolic JC-1 aggregate formation at high membrane potentials in control cells (red fluorescence). Furthermore, this assay showed a dominant effect of $50 \mu \mathrm{g} / \mathrm{ml} \mathrm{Bl}$ extract on early intrinsic apoptosis of K562 cells for 24-h treatment (Fig. 4B) compared to K562 (COX-2 ${ }^{+}$) cells (Fig. 4C).

\section{A}

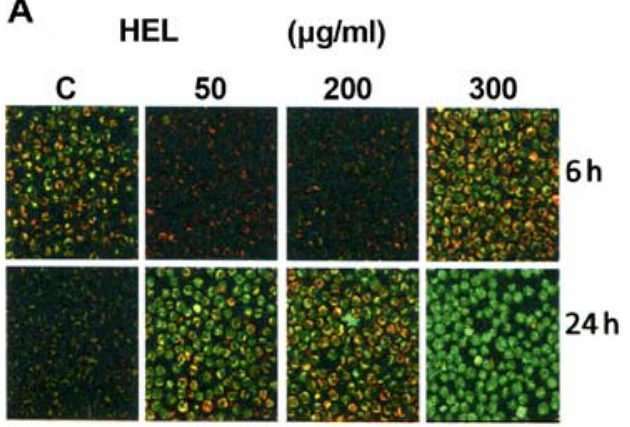

B

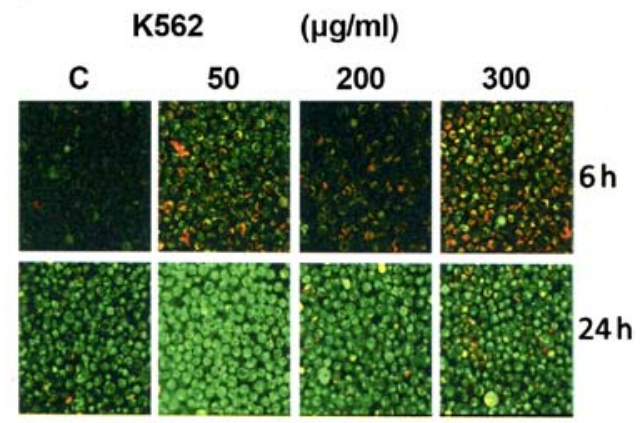

C

K562

$(\mathrm{COX}-2+) \quad(\mu \mathrm{g} / \mathrm{ml})$

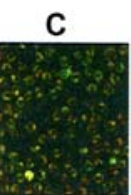

50

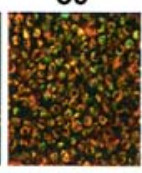

200

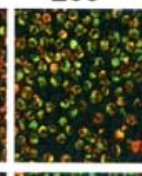

300
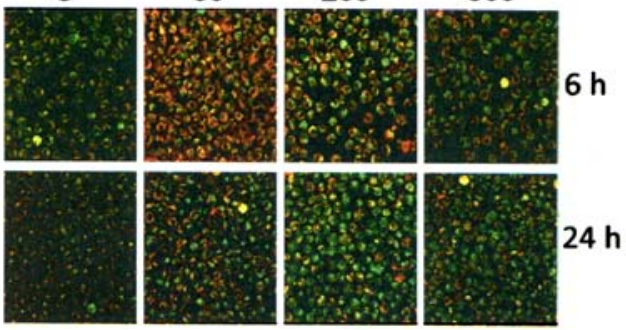

Figure 4. Effect of $B l$ extract on HEL (A), K562 (B) and K562 (COX-2 $\left.2^{+}\right)(\mathrm{C})$ cell mitochondrial membrane potential. Cells were cultured in $10 \%$ FCS medium for $24 \mathrm{~h}$ and treated or not with $B l$ extract at $50-300 \mu \mathrm{g} / \mathrm{ml}$ for 6 and $24 \mathrm{~h}$. After treatment, cells were incubated with medium containing JC-1 $(1 \mu \mathrm{g} /$ $\mathrm{ml}$ ) for $30 \mathrm{~min}$ at $37^{\circ} \mathrm{C}$. Red fluorescence represents mitochondria with intact membrane potential whereas green fluorescence represents de-energized mitochondria. Images were taken with a confocal laser microscope (Zeiss LSM 510 Meta) (x100). The images are representative of three separate experiments. 


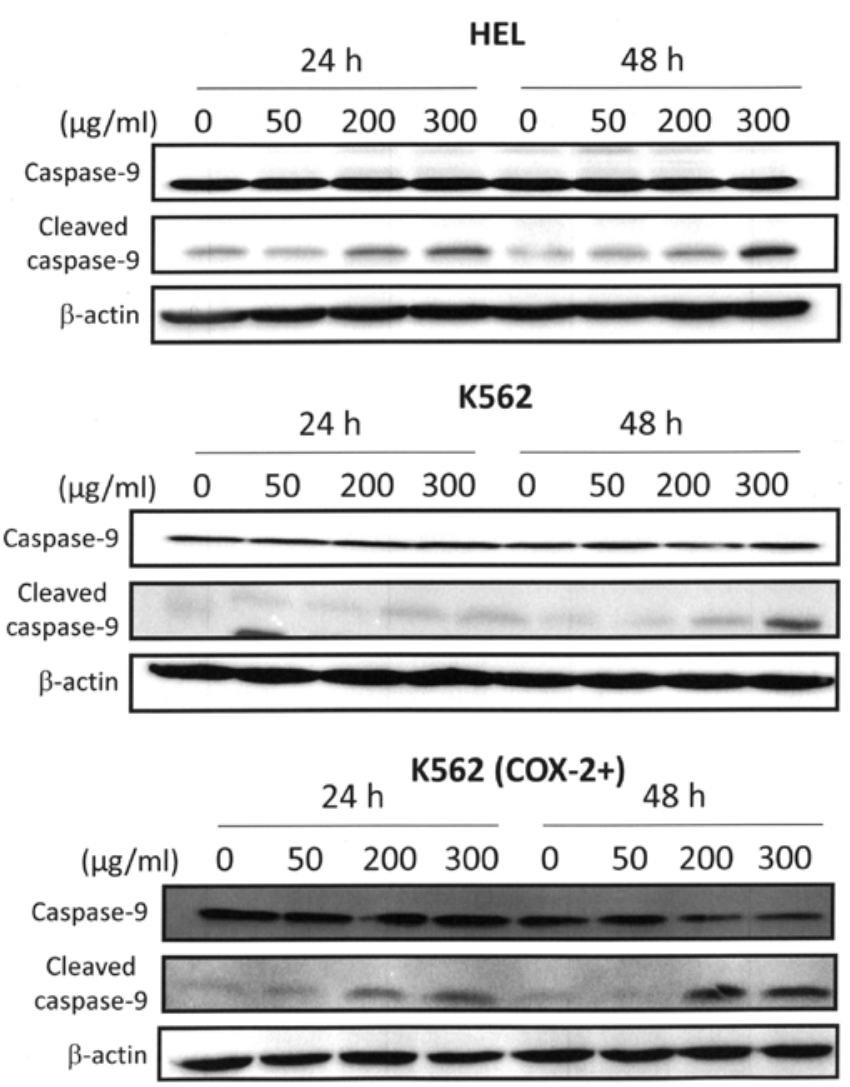

Figure 5. Effect of $\mathrm{Bl}$ extract on caspase-9 expression in human erythroleukemia cells. Cells were cultured in $10 \%$ FCS medium for $24 \mathrm{~h}$ and treated or not with 50-300 $\mu \mathrm{g} / \mathrm{ml} \mathrm{Bl}$ extract for 24 and $48 \mathrm{~h}$. Protein expression was analyzed by western blotting. $\beta$-actin was used as a loading control. Blots are representative of three separate experiments.
Caspase- 3 is a key executioner of apoptosis, its activation is mediated by the initiator caspases such as caspase- 8 and caspase-9 (45). In our study, we showed that intrinsic apoptosis pathway was implicated in $B l$ extract-induced apoptosis in human erythroleukemia cells. Indeed, we showed that $B l$ extract induced an activation of caspase- 9 especially at $300 \mu \mathrm{g} / \mathrm{ml}$ after 48 -h treatment as shown in Fig. 5. Bl extract induced a cleavage of caspase- 9 at $48 \mathrm{~h}$ but the expression of cleaved fragment of caspase- 9 after $300 \mu \mathrm{g} / \mathrm{ml} \mathrm{Bl}$ extract treatment for HEL and $\mathrm{K} 562\left(\mathrm{COX}-2^{+}\right)$cells was more important than in K562 cells. Consequently, $300 \mu \mathrm{g} / \mathrm{ml} \mathrm{Bl}$ extract induced activation of executive caspase- 3 activity in the three cell lines ( +3 -fold versus control at $48 \mathrm{~h}$ for HEL cells, +6 -fold versus control at $48 \mathrm{~h}$ for K562 cells, and +5 -fold versus control at $48 \mathrm{~h}$ for K562 (COX-2 $)$ cells, p<0.05) (Fig. 6). These observations were directly correlated with PARP cleavage because western blot analysis detected the cleaved form of PARP in $300 \mu \mathrm{g} / \mathrm{ml}$ $B l$ extract treated cells (Fig. 7). Cleaved fragment of PARP was expressed starting at $24 \mathrm{~h}$ for $300 \mu \mathrm{g} / \mathrm{ml} \mathrm{Bl} \mathrm{extract} \mathrm{treatment}$ and strongly maintained after 48 -h treatment (Fig. 7). PARP is a nuclear enzyme involved in the repair of DNA damage (46). Moreover, it is known that PARP is a substrate for caspases such as caspase- 3 and is typically cleaved and inactivated during the apoptotic process (47).

DNA fragmentation occurs simultaneously with this phenomenon and is considered as a major marker of apoptotic cells. DNA fragmentation was observed in human erythroleukemia cells after $B l$ extract treatment. Quantitative determination of cytoplasmic histone-associated DNA fragments (mono and oligonucleosomes) was performed by ELISA in our study. Results showed that DNA fragmentation was
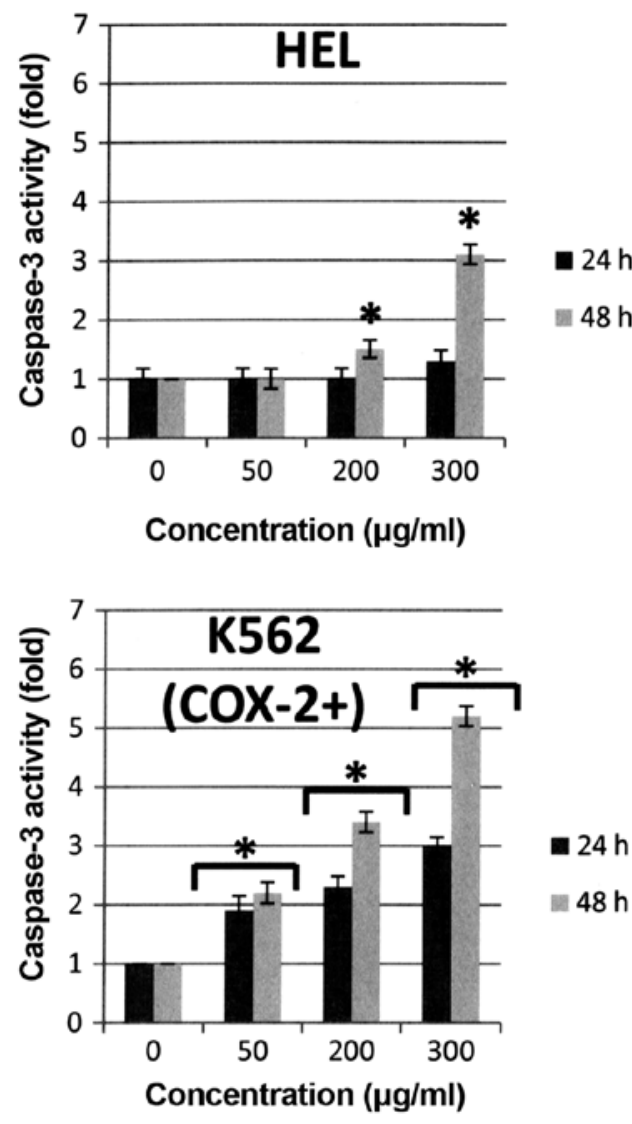

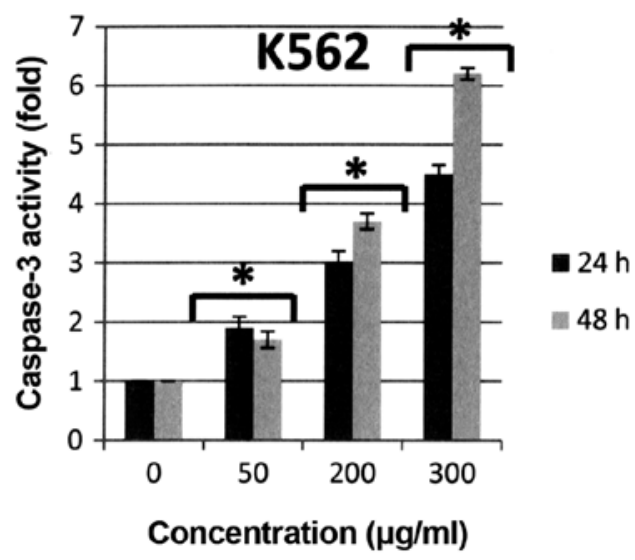

Figure 6. Effect of $B l$ extract on caspase-3 activity in human erythroleukemia cells. Cells were cultured in $10 \%$ FCS medium for $24 \mathrm{~h}$ and treated or not with $50-300 \mu \mathrm{g} / \mathrm{ml} \mathrm{Bl}$ extract for 24 and $48 \mathrm{~h}$. Caspase- 3 activity was assayed using Quantikine human active caspase-3 (R\&D Systems). Following treatment, cells were incubated with $10 \mu \mathrm{M}$ biotin-ZVKD-fmk inhibitor for $1 \mathrm{~h}$ at $37^{\circ} \mathrm{C}$. The amount of active caspase- 3 was quantified by colorimetry at $450 \mathrm{~nm}$; values are expressed as mean $\pm \mathrm{SD}$ of three separate experiments and reported as $\mathrm{n}$-fold $\left({ }^{*} \mathrm{p}<0.05\right)$ compared to control. 


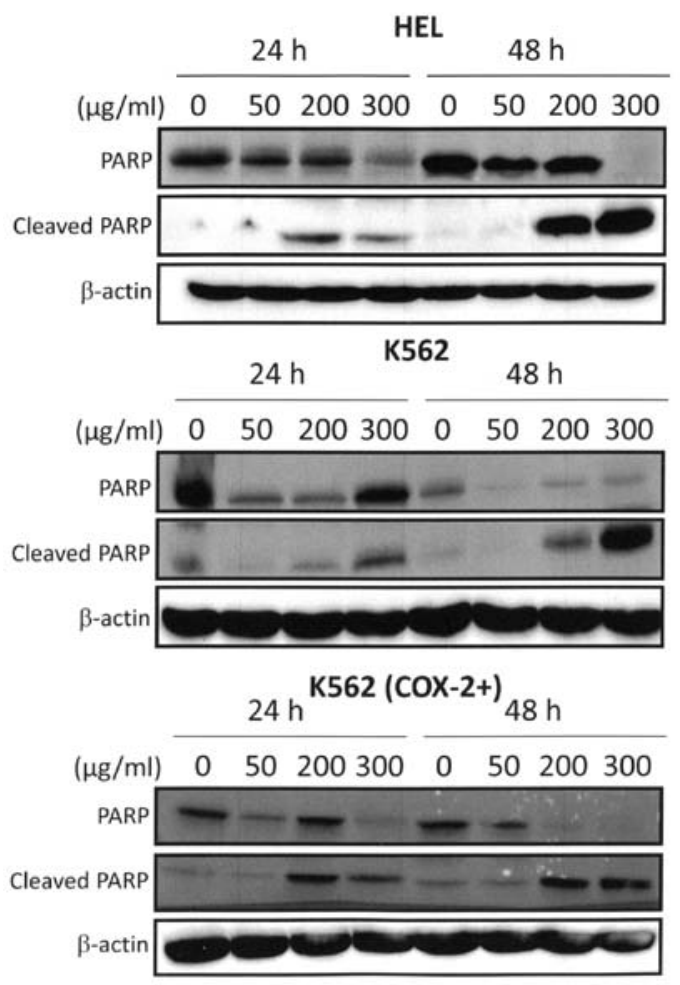

Figure 7. Effect of $\mathrm{Bl}$ extract on PARP cleavage in human erythroleukemia cells. Cells were cultured in $10 \%$ FCS medium for $24 \mathrm{~h}$ and treated or not with $50-300 \mu \mathrm{g} / \mathrm{ml} B l$ extract for 24 and $48 \mathrm{~h}$. PARP cleavage was analyzed by western blotting. PARP cleavage was assessed by detection of the $85-\mathrm{kDa}$ band (cleaved PARP) after probing with a mouse anti-human PARP antibody. $\beta$-actin was used as a loading control. Blots are representative of three separate experiments.
HEL

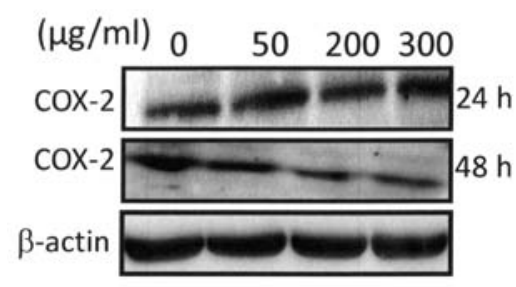

K562 (COX-2+)

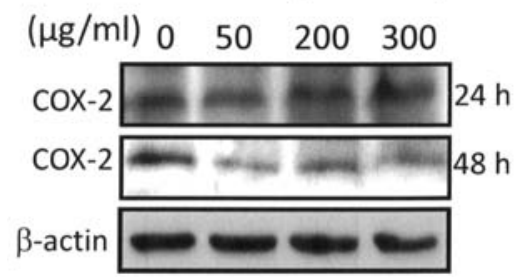

Figure 9. Effect of $B l$ extract on COX-2 expression. HEL and K562 (COX-2+) cells were cultured in $10 \%$ FCS medium for $24 \mathrm{~h}$ and treated or not with $50-300 \mu \mathrm{g} / \mathrm{ml} \mathrm{Bl}$ extract for 24 and $48 \mathrm{~h}$. COX-2 expression was determined by western blot analysis. $\beta$-actin was used as a loading control. Blots are representative of three separate experiments.

strongly induced in the three cell lines after $48-\mathrm{h} B l$ extract treatment $[+3.3-,+6.5$ and +5.8 -fold versus control respectively for HEL, K562 and K562 (COX-2 $)$, p $<0.05$ ] (Fig. 8). It is important to note that DNA fragmentation is the strongest in K562 cells not expressing COX-2.

\section{HEL}

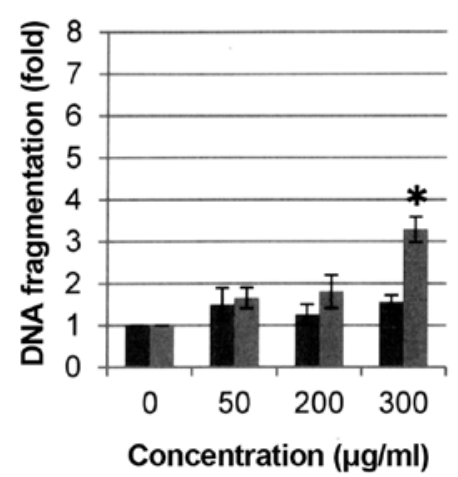

K562 (COX-2+)

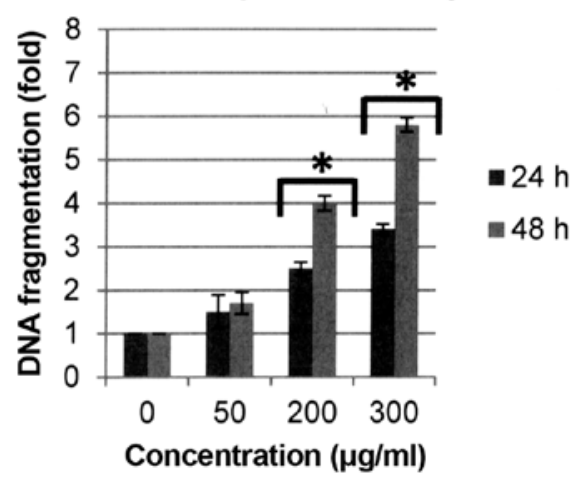

K562

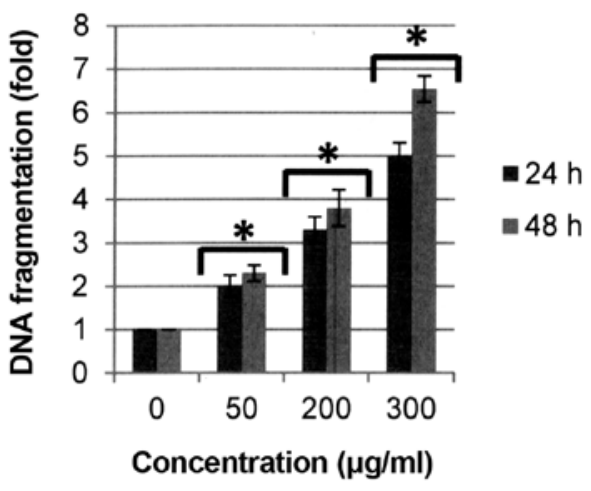

Figure 8. Effect of $B l$ extract on DNA fragmentation in human erythroleukemia cells. Cells were cultured in $10 \%$ FCS medium for $24 \mathrm{~h}$ and treated or not with $50-300 \mu \mathrm{g} / \mathrm{ml} \mathrm{Bl}$ extract for 24 and $48 \mathrm{~h}$. DNA fragmentation was quantified from cytosol extracts according to the manufacturer's instructions (Cell Death Detection ELISAplus, Roche Diagnostics). Results were reported as n-fold compared to control. Values are expressed as mean $\pm \mathrm{SD}$ (p-value relative to control group, $\left.{ }^{*} \mathrm{p}<0.05\right)$. 


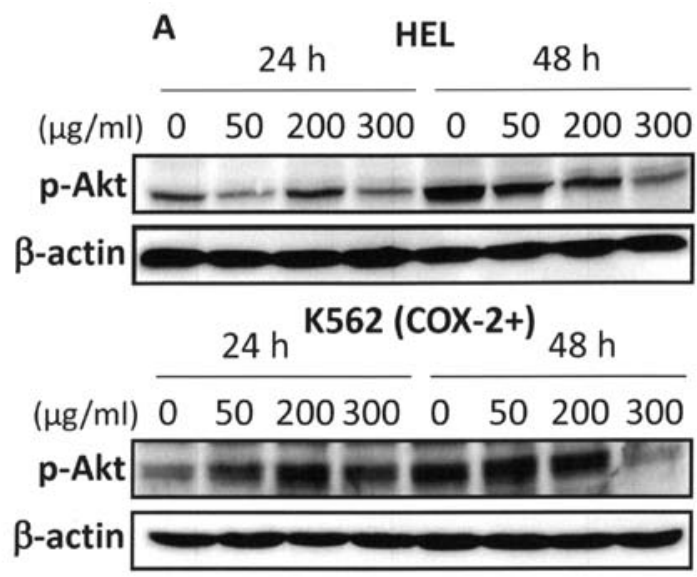

B

HEL $300 \mu \mathrm{g} / \mathrm{ml}$

C $12 \mathrm{~h} 24 \mathrm{~h} 48 \mathrm{~h}$

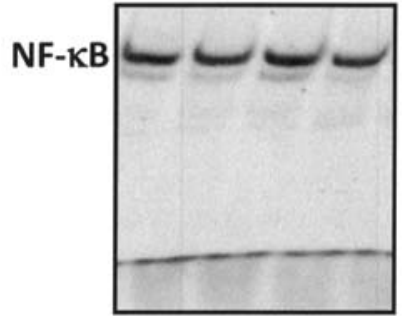

K562 (COX-2+) $300 \mu \mathrm{g} / \mathrm{ml}$

C $12 \mathrm{~h} 24 \mathrm{~h} 48 \mathrm{~h}$

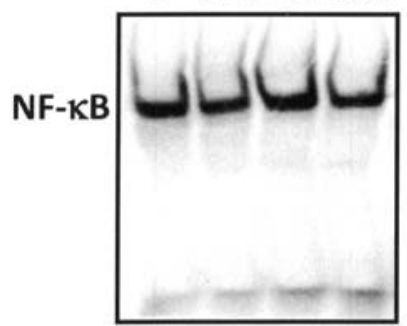

Figure 10. Effect of $\mathrm{Bl}$ extract on p-Akt expression and NF- $\mathrm{\kappa B}$ activation. HEL and K562 (COX-2 $2^{+}$cells were cultured in 10\% FCS medium for $24 \mathrm{~h}$ and treated or not with $50-300 \mu \mathrm{g} / \mathrm{ml} \mathrm{Bl}$ extract for 24 and $48 \mathrm{~h}$. Akt phosphorylation (A) was determined by western blot analysis. $\beta$-actin was used as a loading control. Blots are representative of three separate experiments (B) EMSA experiments were performed using DIG Gel Shift kit (Roche Diagnostics) on nuclear extracts. Blots are representative of three separate experiments.
In summary, even if $B l$ extract induced apoptosis of three human erythroleukemia cell lines, a dominant effect of $\mathrm{Bl}$ extract treatment on K562 cells was observed resulting in activation of the late markers of apoptosis with caspase-3 activation, PARP cleavage and DNA fragmentation.

It is well known that COX-2 expression is correlated with the activities of intracellular signalling proteins such as $\mathrm{NF}-\kappa \mathrm{B}(48)$. Furthermore, we showed recently that COX-2 positively regulated Akt signalling and enhanced survival of cancer cells exposed to anticancer agents (35). Numerous studies have shown that COX-2 expression prevents apoptosis in cancer cells, especially in colon $(49,50)$ and prostate cancer (51-53). Here, we showed that $B l$ extract reduced significantly expression of COX-2 by a dose-dependent manner at $48-\mathrm{h}$ treatment in HEL and K562 (COX-2 $2^{+}$) cells (Fig. 9).

Among the cell signalling pathways that promote cell survival, Akt is one of the most important (54). Activated Akt can also exert anti-apoptotic effects, positively regulate NF- $\kappa \mathrm{B}$ transcription, modulate angiogenesis, promote tumor invasion/metastasis and antagonize cell cycle arrest (55). Akt is also reported to modulate the NF- $\mathrm{kB}$ transcription factor through the phosphorylation of p65 to enhance the transcriptional activity of NF- $\kappa B$ (56). In turn, NF- $\kappa B$ activation can regulate the expression of cell survival, proliferative, metastatic and angiogenic gene products (57). We analyzed the effect of $B l$ extract on two survival pathways: Akt and NF- $\kappa B$. Western blot analysis showed that $300 \mu \mathrm{g} /$ $\mathrm{ml} \mathrm{Bl}$ extract markedly inhibited Akt phosphorylation in HEL and K562 (COX-2 ${ }^{+}$) cells at 48-h treatment (Fig. 10A). Since NF- $\mathrm{KB}$ activation is critical for apoptosis resistance, we examined the effect of $B l$ extract on nuclear activation of NF- $\kappa B$. Our results showed that $300 \mu \mathrm{g} / \mathrm{ml} \mathrm{Bl}$ extract inhibited NF- $\kappa$ B activation at 12- and 48-h treatment (Fig. 10B).
HEL

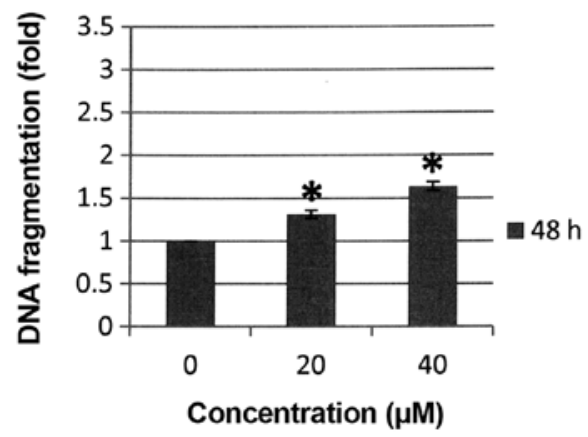

K562

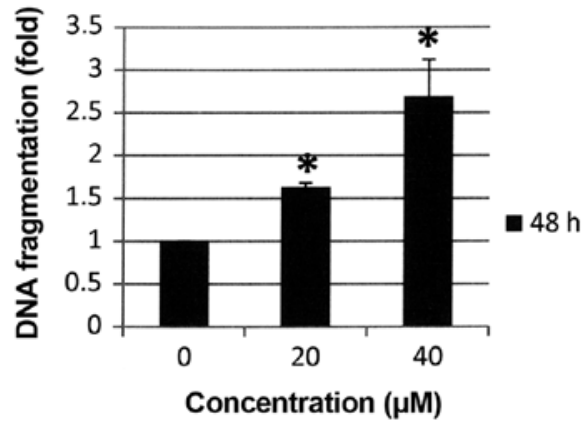

Figure 11. Effect of berberine on DNA fragmentation in human erythroleukemia cells. Cells were cultured in $10 \%$ FCS medium for $24 \mathrm{~h}$ and treated or not with 20 or $40 \mu \mathrm{M}$ berberine for $48 \mathrm{~h}$. DNA fragmentation was quantified from cytosol extracts according to the manufacturer's instructions (Cell Death Detection ELISAplus). Results were reported as $n$-fold compared to control. Values are expressed as mean $\pm \mathrm{SD}$ ( $\mathrm{p}$-value relative to control group, $\left.{ }^{\mathrm{p}} \mathrm{p}<0.05\right)$.

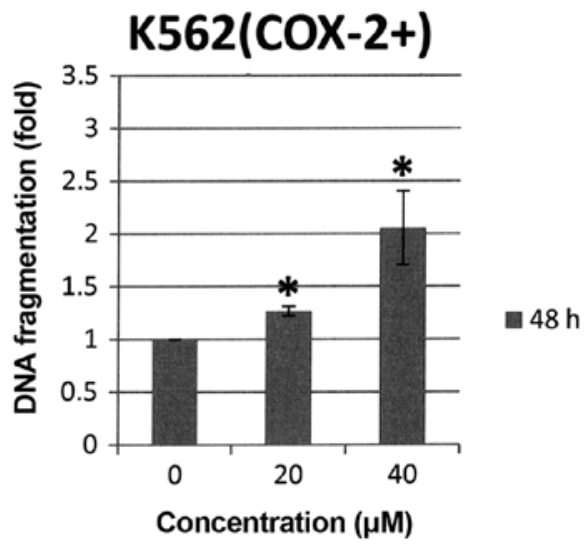




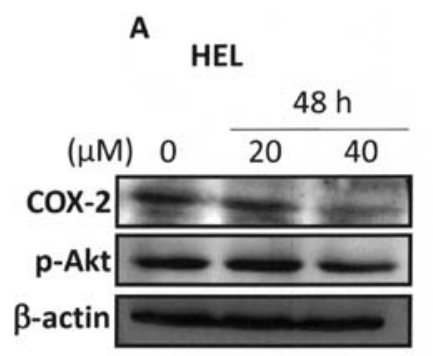

B

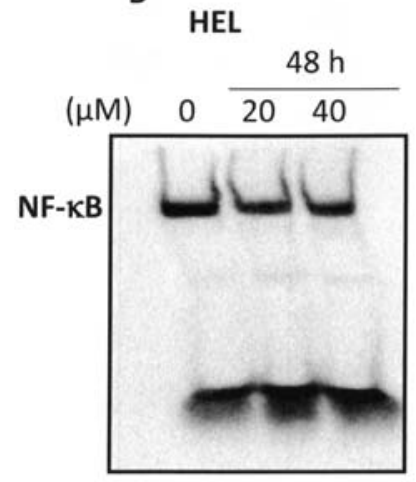

K562 (COX-2+)

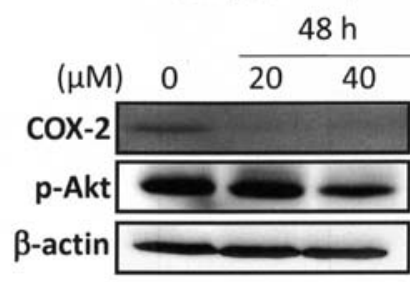

K562 (COX-2+)

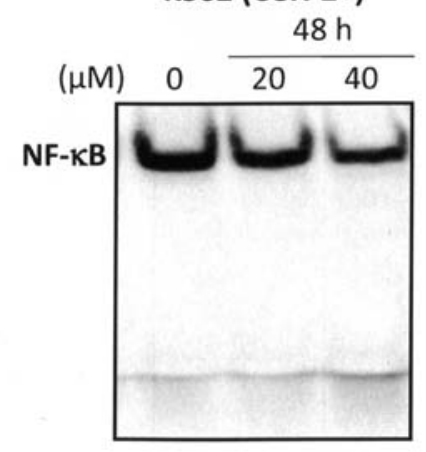

Figure 12. Effect of berberine on COX-2 and p-Akt expression and NF- $\kappa \mathrm{B}$ activation. HEL and K562 (COX-2 $2^{+}$) cells were cultured in $10 \%$ FCS medium for $24 \mathrm{~h}$ and treated or not with 20 or $40 \mu \mathrm{M}$ berberine for $48 \mathrm{~h}$. COX-2 expression and Akt phosphorylation (A) were determined by western blot analysis. $\beta$-actin was used as a loading control. Blots are representative of three separate experiments. (B) EMSA experiments were performed using DIG Gel Shift kit on nuclear extracts. Blots are representative of three separate experiments.

In regard to these results, it is clear that the simultaneous inhibition of Akt and NF- $\mathrm{NB}$ signalling can significantly contribute to the anticancer effects of $B l$ extract in human erythroleukemia cells.

The results of $B l$ extract HPLC profile showed that berberine is the major product (Fig. 1), thus, we then tested this molecule on the induction of DNA fragmentation, the expression of COX-2 and phospho-Akt (p-Akt) and the activation of $\mathrm{NF}-\kappa \mathrm{B}$. From the report of Bonesi et al giving the chemical composition of $B l$ extract, $300 \mu \mathrm{g} / \mathrm{ml}$ of our $B l$ extract would correspond to $40 \mu \mathrm{M}$ of pure berberine (13). Based on these calculations, we then tested berberine in 20 and $40 \mu \mathrm{M}$ on human erythroleukemia cells. Our results showed that especially $40 \mu \mathrm{M}$ berberine induced DNA fragmentation of three cell lines [+1.6-fold for HEL cells, +2.7-fold for K562 cells and +2-fold for K562 (COX-2 $2^{+}$versus control, p<0.05] (Fig. 11). Whereas, western blot analysis showed that $40 \mu \mathrm{M}$ berberine markedly inhibited COX-2 expression and Akt phosphorylation in HEL and K562 (COX-2 ${ }^{+}$) cells at 48-h treatment (Fig. 12A). Furthermore, our results showed that $40 \mu \mathrm{M}$ berberine inhibited NF- $\kappa$ B activation at 48-h treatment (Fig. 12B). Recently, Fu et al demonstrated that berberine inhibited human nonsmall cell lung cancer cell growth by simultaneously targeting NF- $\kappa \mathrm{B} / \mathrm{COX}-2$, PI3K/Akt and caspase signalling pathways (58). Furthermore, others studies showed an antitumor effect of berberine via inhibition of $\mathrm{NK}-\kappa \mathrm{B}$ pathway and induction of apoptosis $(59,60)$.

Our results clearly indicate for the first time that $B l$ extract exert their potent anti-proliferative and pro-apoptotic effects through the modulation of $\mathrm{Akt} / \mathrm{NF}-\kappa \mathrm{B} / \mathrm{COX}-2$ signal trans- duction pathways in human erythroleukemia cells and do not act specifically on any one cellular signalling cascade. It is obvious that $B l$ extract is not active against a specific signalling cascade but it can interfere with a multitude of targets in human erythroleukemia cells. This is quite relevant to the changing paradigm in cancer therapy, as increasing evidence indicates that the mono-targeted drugs, once called smart drugs, have not had a significant impact on cancer treatment and the use of multi-targeted drugs has become increasingly accepted, as it is obvious that cancer is caused by dysregulation of multiple pathways (61). Our results show that $B l$ extract has a dominant effect on K562 cells do not expressing COX-2 compared to HEL and K562 (COX-2 $\left.{ }^{+}\right)$cells. Furthermore, the significance of our in vitro study between $B l$ extract and berberine effects in human erythroleukemia cells is very encouraging suggesting the relevance of testing these compounds in xenograft animal models.

\section{Acknowledgements}

We thank Claire CARRION (UMR CNRS 7276, Platform CIM) for the analyses of imaging. This study was supported by grants from the French Ministry of Education and Research and from the Lebanese University.

\section{References}

1. Smith WL, DeWitt DL and Garavito RM: Cyclooxygenases: Structural, cellular, and molecular biology. Annu Rev Biochem 69: $145-182,2000$

2. Wang D and Dubois RN: Eicosanoids and cancer. Nat Rev Cancer 10: 181-193, 2010.

3. Cao Y and Prescott SM: Many actions of cyclooxygenase-2 in cellular dynamics and in cancer. J Cell Physiol 190: 279-286, 2002.

4. Zha S, Yegnasubramanian V, Nelson WG, Isaacs WB and De Marzo AM: Cyclooxygenases in cancer: Progress and perspective. Cancer Lett 215: 1-20, 2004.

5. Subbaramaiah K and Dannenberg AJ: Cyclooxygenase 2: A molecular target for cancer prevention and treatment. Trends Pharmacol Sci 24: 96-102, 2003.

6. Bernard MP, Bancos S, Sime PJ and Phipps RP: Targeting cyclooxygenase-2 in hematological malignancies: Rationale and promise. Curr Pharm Des 14: 2051-2060, 2008.

7. Chien MH, Ku CC, Johansson G, Chen MW, Hsiao M, Su JL, Inoue H, Hua KT, Wei LH and Kuo ML: Vascular endothelial growth factor-C (VEGF-C) promotes angiogenesis by induction of COX-2 in leukemic cells via the VEGF-R3/JNK/ AP-1 pathway. Carcinogenesis 30: 2005-2013, 2009.

8. Zheng J, Chen S, Jiang L, You Y, Wu D and Zhou Y: Functional genetic variations of cyclooxygenase-2 and susceptibility to acute myeloid leukemia in a Chinese population. Eur J Haematol 87: 486-493, 2011.

9. Santos FP, Bueso-Ramos CE and Ravandi F: Acute erythroleukemia: Diagnosis and management. Expert Rev Hematol 3: 705-718, 2010.

10. Nakanishi Y, Kamijo R, Takizawa K, Hatori M and Nagumo M: Inhibitors of cyclooxygenase-2 (COX-2) suppressed the proliferation and differentiation of human leukaemia cell lines. Eur $\mathbf{J}$ Cancer 37: 1570-1578, 2001.

11. Subhashini J, Mahipal SV and Reddanna P: Anti-proliferative and apoptotic effects of celecoxib on human chronic myeloid leukemia in vitro. Cancer Lett 224: 31-43, 2005.

12. Cervi D, Klement G, Stempak D, Baruchel S, Koki A and Ben-David Y: Targeting cyclooxygenase-2 reduces overt toxicity toward low-dose vinblastine and extends survival of juvenile mice with Friend disease. Clin Cancer Res 11: 712-719, 2005.

13. Bonesi M, Loizzo MR, Conforti F, Passalacqua NG, Saab A, Menichini $\mathrm{F}$ and Tundis R: Berberis aetnensis and B. libanotica: A comparative study on the chemical composition, inhibitory effect on key enzymes linked to Alzheimer's disease and antioxidant activity. J Pharm Pharmacol 65: 1726-1735, 2013. 
14. El Beyrouthy M, Arnold N, Delelis-Dusollier A and Dupont F: Plants used as remedies antirheumatic and antineuralgic in the traditional medicine of Lebanon. J Ethnopharmacol 120: 315-334, 2008

15. Imanshahidi $M$ and Hosseinzadeh $\mathrm{H}$ : Pharmacological and therapeutic effects of Berberis vulgaris and its active constituent, berberine. Phytother Res 22: 999-1012, 2008.

16. Zovko Koncić M, Kremer D, Karlović K and Kosalec I: Evaluation of antioxidant activities and phenolic content of Berberis vulgaris L. and Berberis croatica Horvat. Food Chem Toxicol 48: 2176-2180, 2010.

17. Kim S, Choi JH, Kim JB, Nam SJ, Yang JH, Kim JH and Lee JE: Berberine suppresses TNF-alpha-induced MMP-9 and cell invasion through inhibition of AP-1 activity in MDA-MB-231 human breast cancer cells. Molecules 13: 2975-2985, 2008.

18. Singh J and Kakkar P: Antihyperglycemic and antioxidant effect of Berberis aristata root extract and its role in regulating carbohydrate metabolism in diabetic rats. J Ethnopharmacol 123 : 22-26, 2009

19. Roberts MF and Wink M(eds): Alkaloids: Biochemistry, Ecology, and Medicinal applications. Springer, New York, London, 1998.

20. Aniszewski T: Alkaloids-Secrets of Life: Alkaloid Chemistry, Biological Significance, Applications and Ecological Role. Elsevier, Amsterdam, Oxford, 2007

21. Huang M, Gao H, Chen Y, Zhu H, Cai Y, Zhang X, Miao Z, Jiang H, Zhang J, Shen H, et al: Chimmitecan, a novel 9-substituted camptothecin, with improved anticancer pharmacologic profiles in vitro and in vivo. Clin Cancer Res 13: 1298-1307, 2007.

22. Li W, Shao Y, Hu L, Zhang X, Chen Y, Tong L, Li C, Shen X and Ding J: BM6, a new semi-synthetic vinca alkaloid, exhibits its potent in vivo anti-tumor activities via its high binding affinity for tubulin and improved pharmacokinetic profiles. Cancer Biol Ther 6: 787-794, 2007.

23. Singh T, Vaid M, Katiyar N, Sharma S and Katiyar SK Berberine, an isoquinoline alkaloid, inhibits melanoma cancer cell migration by reducing the expressions of cyclooxygenase-2, prostaglandin $\mathrm{E}_{2}$ and prostaglandin $\mathrm{E}_{2}$ receptors. Carcinogenesis 32: 86-92, 2011

24. Ho YT, Yang JS, Lu CC, Chiang JH, Li TC, Lin JJ, Lai KC, Liao CL, Lin JG and Chung JG: Berberine inhibits human tongue squamous carcinoma cancer tumor growth in a murine xenograft model. Phytomedicine 16: 887-890, 2009.

25. Refaat A, Abdelhamed S, Yagita H, Inoue H, Yokoyama S, Hayakawa Y and Saiki I: Berberine enhances tumor necrosis factor-related apoptosis-inducing ligand-mediated apoptosis in breast cancer. Oncol Lett 6: 840-844, 2013.

26. Liu B, Wang G, Yang J, Pan X, Yang Z and Zang L: Berberine inhibits human hepatoma cell invasion without cytotoxicity in healthy hepatocytes. PLoS One 6: e21416, 2011.

27. Peng PL, Hsieh YS, Wang CJ, Hsu JL and Chou FP: Inhibitory effect of berberine on the invasion of human lung cancer cells via decreased productions of urokinase-plasminogen activator and matrix metalloproteinase-2. Toxicol Appl Pharmacol 214: 8-15, 2006.

28. Esseily F, El-Ezzy M, Gali-Muhtasib H, Safi S, Esseily J, Diab-Assaf M, Lampronti I and Saab A: The ethanol fraction from the stem of Berberis libanotica inhibits the viability of adult T cell leukemia. Minerva Biotecnol 24: 129-133, 2012.

29. El-Merahbi R, Liu YN, Eid A, Daoud G, Hosry L, Monzer A, Mouhieddine TH, Hamade A, Najjar F and Abou-Kheir W: Berberis libanotica Ehrenb extract shows anti-neoplastic effects on prostate cancer stem/progenitor cells. PLoS One 9: e112453, 2014.

30. Gritsanapan W and Mangmeesri P: Standardized Senna alata leaf extract. J Health Res 23: 59-64, 2009.

31. Corbiere C, Liagre B, Terro F and Beneytout JL: Induction of antiproliferative effect by diosgenin through activation of p53, release of apoptosis-inducing factor (AIF) and modulation of caspase-3 activity in different human cancer cells. Cell Res 14 188-196, 2004.

32. Smiley ST, Reers M, Mottola-Hartshorn C, Lin M, Chen A, Smith TW, Steele GD Jr and Chen LB: Intracellular heterogeneity in mitochondrial membrane potentials revealed by a J-aggregate-forming lipophilic cation JC-1. Proc Natl Acad Sci USA 88: 3671-3675, 1991.

33. Lepage C, Léger DY, Bertrand J, Martin F, Beneytout JL and Liagre B: Diosgenin induces death receptor-5 through activation of p38 pathway and promotes TRAIL-induced apoptosis in colon cancer cells. Cancer Lett 301: 193-202, 2011.
34. Leger DY, Liagre B and Beneytout JL: Role of MAPKs and NF-kappaB in diosgenin-induced megakaryocytic differentiation and subsequent apoptosis in HEL cells. Int J Oncol 28: 201-207, 2006.

35. Bertrand J, Liagre B, Ghezali L, Beneytout JL and Leger DY Cyclooxygenase-2 positively regulates Akt signalling and enhances survival of erythroleukemia cells exposed to anticancer agents. Apoptosis 18: 836-850, 2013.

36. Ghezali L, Leger DY, Limami Y, Cook-Moreau J, Beneytout JL and Liagre B: Cyclopamine and jervine induce COX-2 overexpression in human erythroleukemia cells but only cyclopamine has a pro-apoptotic effect. Exp Cell Res 319: 1043-1053, 2013.

37. Tsujii M and DuBois RN: Alterations in cellular adhesion and apoptosis in epithelial cells overexpressing prostaglandin endoperoxide synthase 2. Cell 83: 493-501, 1995 .

38. Dannenberg AJ, Altorki NK, Boyle JO, Dang C, Howe LR, Weksler BB and Subbaramaiah K: Cyclo-oxygenase 2: A pharmacological target for the prevention of cancer. Lancet Oncol 2: 544-551, 2001.

39. Fürstenberger G, Krieg P, Müller-Decker K and Habenicht AJ: What are cyclooxygenases and lipoxygenases doing in the driver's seat of carcinogenesis? Int J Cancer 119: 2247-2254, 2006.

40. Ryan EP, Pollock SJ, Kaur K, Felgar RE, Bernstein SH, Chiorazzi N and Phipps RP: Constitutive and activation-inducible cyclooxygenase-2 expression enhances survival of chronic lymphocytic leukemia B cells. Clin Immunol 120: 76-90, 2006.

41. Hengartner MO: The biochemistry of apoptosis. Nature 407: $770-776,2000$

42. Zamzami N, Susin SA, Marchetti P, Hirsch T, GómezMonterrey I, Castedo M and Kroemer G: Mitochondrial control of nuclear apoptosis. J Exp Med 183: 1533-1544, 1996.

43. Green D and Kroemer G: The central executioners of apoptosis: Caspases or mitochondria? Trends Cell Biol 8: 267-271, 1998.

44. Liu X, Kim CN, Yang J, Jemmerson R and Wang X: Induction of apoptotic program in cell-free extracts: Requirement for dATP and cytochrome $c$. Cell 86: 147-157, 1996.

45 Salvesen GS and Dixit VM: Caspases: Intracellular signaling by proteolysis. Cell 91: 443-446, 1997.

46. D'Amours D, Desnoyers S, D'Silva I and Poirier GG: Poly(ADPribosyl)ation reactions in the regulation of nuclear functions. Biochem J 342: 249-268, 1999.

47. Nicholson DW: Caspase structure, proteolytic substrates, and function during apoptotic cell death. Cell Death Differ 6: 1028-1042, 1999.

48. Giri DK and Aggarwal BB: Constitutive activation of NF-kappaB causes resistance to apoptosis in human cutaneous T cell lymphoma HuT-78 cells. Autocrine role of tumor necrosis factor and reactive oxygen intermediates. J Biol Chem 273: 14008-14014, 1998.

49. Wang D and Dubois RN: The role of COX-2 in intestinal inflammation and colorectal cancer. Oncogene 29: 781-788, 2010.

50. Limami Y, Pinon A, Leger DY, Mousseau Y, Cook-Moreau J, Beneytout JL, Delage C, Liagre B and Simon A: HT-29 colorectal cancer cells undergoing apoptosis overexpress COX-2 to delay ursolic acid-induced cell death. Biochimie 93: 749-757, 2011.

51. Kirschenbaum A, Liu X, Yao S and Levine AC: The role of cyclooxygenase-2 in prostate cancer. Urology 58 (Suppl 1): 127-131, 2001.

52. Lee KS, Lee HJ, Ahn KS, Kim SH, Nam D, Kim DK, Choi DY, Ahn KS, Lu J and Kim SH: Cyclooxygenase-2/prostaglandin E2 pathway mediates icariside II induced apoptosis in human PC-3 prostate cancer cells. Cancer Lett 280: 93-100, 2009.

53. Limami Y, Pinon A, Leger DY, Pinault E, Delage C, Beneytout JL, Simon A and Liagre B: The P2Y2/Src/p38/COX-2 pathway is involved in the resistance to ursolic acid-induced apoptosis in colorectal and prostate cancer cells. Biochimie 94: 1754-1763, 2012.

54. Chen X, Thakkar H, Tyan F, Gim S, Robinson H, Lee C, Pandey SK, Nwokorie C, Onwudiwe N and Srivastava RK: Constitutively active Akt is an important regulator of TRAIL sensitivity in prostate cancer. Oncogene 20: 6073-6083, 2001.

55. Testa JR and Bellacosa A: AKT plays a central role in tumorigenesis. Proc Natl Acad Sci USA 98: 10983-10985, 2001.

56. Madrid LV, Mayo MW, Reuther JY and Baldwin AS Jr: Akt stimulates the transactivation potential of the RelA/p65 Subunit of NF-kappa B through utilization of the Ikappa B kinase and activation of the mitogen-activated protein kinase p38. J Biol Chem 276: 18934-18940, 2001.

57. Ahn KS, Sethi G and Aggarwal BB: Nuclear factor-kappa B: From clone to clinic. Curr Mol Med 7: 619-637, 2007. 
58. Fu L, Chen W, Guo W, Wang J, Tian Y, Shi D, Zhang X, Qiu H, Xiao X, Kang T, et al: Berberine targets AP-2/hTERT, NF- $\mathrm{kB} /$ COX-2, HIF-1 $\alpha$ /VEGF and cytochrome-c/caspase signaling to suppress human cancer cell growth. PLoS One 8: e69240, 2013.

59. Muralimanoharan SB, Kunnumakkara AB, Shylesh B, Kulkarni KH, Haiyan X, Ming H, Aggarwal BB, Rita G and Kumar AP: Butanol fraction containing berberine or related compound from nexrutine inhibits NFkappaB signaling and induces apoptosis in prostate cancer cells. Prostate 69: 494-504, 2009.
60. Goto H, Kariya R, Shimamoto M, Kudo E, Taura M, Katano H and Okada S: Antitumor effect of berberine against primary

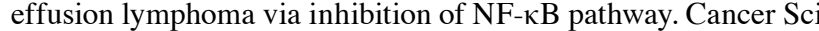
103: 775-781, 2012.

61. Mencher SK and Wang LG: Promiscuous drugs compared to selective drugs (promiscuity can be a virtue). BMC Clin Pharmacol 5: 3, 2005. 